\title{
ACCESS DENIED? INCONSISTENT JURISPRUDENCE ON THE OPEN COURT PRINCIPLE AND MEDIA ACCESS TO EXHIBITS IN CANADIAN CRIMINAL CASES
}

\author{
DANA ADAMS
}

The open court principle is a central tenet of the Canadian justice system. However, in cases involving media access to exhibits entered in court, the courts have been neither clear nor consistent in their interpretation and application of the open court principle. This article discusses the historical development of the open court principle and the definition of an "open court" today. The author proposes that the Supreme Court of Canada should clarify that the open court principle extends to access to exhibits and re-articulate the Dagenais/Mentuck test in order to resolve the inconsistencies regarding the open court principle.

\begin{abstract}
Le principe de l'audience publique est un principe de base du système de justice canadien. Cependant, dans les causes impliquant l'accès des médias aux preuves matérielles présentées, les tribunaux n'ont adopté qui n'est ni claire ni constante dans leur interprétation et application du principe de l'audience publique. Cet article porte sur le développement historique du principe de l'audience publique et la définition "d'audience publique » telle qu'elle existe aujourd'hui. L'auteur propose que la Cour suprême du Canada clarifie le fait que le principe de l'audience publique vaut pour l'accès à la preuve matérielle et exprime de nouveau le test Dagenais/Mentuck afin de régler les incohérences relatives au principe de l'audience publique.
\end{abstract}

\section{TABLE OF CONTENTS}

I. InTRODUCTION ................................... 178

II. Overview of THE Open Court Principle . . . . . . . . . . . . . 179

A. History of the Open Court Principle . . . . . . . . . . . . 179

B. The Law ANd the Open Court Principle $\ldots \ldots \ldots \ldots \ldots \ldots 181$

III. What DOES “OPEN COURT” MEAN TODAY? . . . . . . . . . . . . . . . . . 185

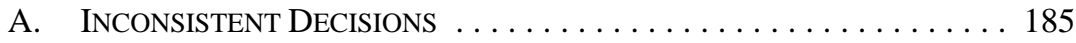

B. Conclusions ............................ 196

IV. What SHOUld “Open Court” MEAN TODAY? . . . . . . . . . . . . . 197

A. A MODEL APPROACH: $R$ V HOGG AND $R V F R Y \ldots \ldots \ldots \ldots \ldots 197$

B. SuPREME Court of CANAdA GuidanCE $\ldots \ldots \ldots \ldots \ldots \ldots 200$

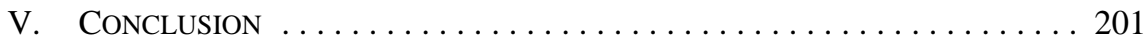

\section{NoTE:}

Since the writing of this article, the Supreme Court of Canada has released a new decision on the issue of media access to exhibits: Canadian Broadcasting Corp $v R^{1}{ }^{1}$ This decision directly answers one of the issues in this article, namely the test to be used for determining whether the media will be granted access to court exhibits for the purpose of broadcast. However, the brevity of the decision (20 paragraphs) means that the Supreme Court does not address many of the other issues discussed in this article, particularly the problems that remain even when courts have cited the proper test, and the reasons why clarification from

* BJ (Hons) (Carleton), LLB (with Distinction) (Alberta). The author would like to thank Sanjeev Anand, Dean, College of Law, University of Saskatchewan, for his support and assistance with earlier drafts of this article. However, any errors or omissions are the author's alone. 
the Supreme Court was necessary. It is the author's hope that this article will provide the background for the Supreme Court's recent decision and raise important issues to be considered before moving forward.

\section{INTRODUCTION}

"In any constitutional climate, the administration of justice thrives on exposure to light and withers under a cloud of secrecy." ${ }^{2}$ This opening statement by Justice Fish in a recent Supreme Court of Canada decision sums up the long-standing and oft-cited rationale for the open court principle in the Canadian justice system. Justice can only truly be done if it is seen to be done - and thus the public must be, and generally is, allowed access to the courts. ${ }^{3}$ This sentiment was instilled in Canadian jurisprudence through the tradition of the British legal system and has remained an integral part of the democratic society valued in Canada. Coinciding with the long tradition of open justice is the acknowledgment that adequate public access to the courts cannot be attained without the presence of the media. The open court principle is founded on public knowledge of the happenings inside Canadian courtrooms, but in reality few Canadians have the time, resources, or ability to sit and watch court proceedings for themselves. Therefore, the media is often the only means through which justice can be brought into the public view.

Although the importance of an open court is well-established in Canadian law, the jurisprudence in recent years demonstrates that courts have been neither clear nor consistent in their interpretation and application of the principle. This confusion has been especially evident in cases involving the question of media access not just to the courtroom, but to the exhibits entered in court proceedings. Some courts have, I would argue rightly, held that the open court principle clearly extends to exhibits entered into evidence. These courts generally, barring some exceptional circumstance, have allowed the media full access to this integral part of proceedings, while other courts have adopted a much narrower interpretation of open justice. This narrow understanding exhibited in many of our country's courtrooms is an affront to the longstanding open court principle, and any tendency to follow such decisions should be halted by the Supreme Court of Canada. As such, the Supreme Court should clarify that the open court principle extends to access to exhibits so that the Canadian public, through the media, can continue to be provided with the greatest possible access to the courts.

Part II of this article will provide an overview of the open court principle, discussing its history and outlining the relevant Canadian law and Supreme Court jurisprudence. Part III will outline what “open court” means today, specifically in relation to court exhibits, through a discussion of recent case law and analysis of why media access was permitted or denied. Part IV of this article will provide suggestions as to what the open court principle should encompass, arguing that the approach of the Manitoba Court of Appeal in $R v \mathrm{Hogg}^{4}$ and the

Toronto Star Newspapers Ltd v Ontario, 2005 SCC 41, [2005] 2 SCR 188 at para 1 [Toronto Star]. The foundation for the open court principle is often described in the literature through the statement of Chief Justice Lord Hewart in Rv Sussex Justices, ex parte McCarthy, [1924] 1 KB 256 at 259: "[J]ustice should not only be done, but should manifestly and undoubtedly be seen to be done.” 2006 MBCA 132, 208 Man R (2d) 244 [Hogg]. 
British Columbia Court of Appeal in $R v$ Fry $^{5}$ are correct and should be adopted by Canada's highest court when it considers the principle.

\section{OVERVIEW OF THE OPEN COURT PRINCIPLE}

\section{A. History of The Open Court Principle}

The Canadian Charter of Rights and Freedoms ${ }^{6}$ has arguably enhanced the media's ability to gain access to the courts, but the open court principle was in existence centuries before the Charter came to be. From their earliest days, Canadian courts have taken up the British common law tradition of open justice, with openness being the general rule and restrictions on access being the exception. ${ }^{7}$ Both British and Canadian decisions on the question of open justice have often quoted, with approval, the eighteenth and nineteenth century English philosopher and author Jeremy Bentham, who was wary of judges’ power in society and who believed that a fair and impartial judiciary could only be attained if the courts were subjected to public scrutiny:

In the darkness of secrecy, sinister interest and evil in every shape have full swing. Only in proportion as publicity has place can any of the checks applicable to judicial injustice operate. Where there is no publicity there is no justice. Publicity is the very soul of justice. It is the keenest spur to exertion and the surest of all guards against improbity. It keeps the judge himself while trying under trial. ${ }^{8}$

Bentham's sentiment regarding the importance of open courts can be found throughout Canadian case law - from the early twentieth century, to cases being decided today. For example, in the 1909 decision in Gazette Printing $v$ Shallow, Justice Duff, as he then was, stated: "The general advantage to the country in having these proceedings made public, more than counterbalances the inconvenience to the private persons whose conduct may be the subject of such proceedings." "Nearly a century later, former Supreme Court Justice Willard Estey echoed the value of open justice: "[P]ublic surveillance of the components of the judicial system performing in the courtroom keeps the process intellectually honest, and at the same time, contributes to the need for the efficiency of the judicial process. Most importantly of all, however, open access to a public trial ensures that the outcome of that trial will be just.” ${ }^{10}$ Countless other statements of approval for the open court principle can be found throughout the jurisprudence - both in the civil and criminal context.

2010 BCCA 169, 317 DLR (4th) 661 [Fry].

Part I of the Constitution Act, 1982, being Schedule B to the Canada Act 1982 (UK), 1982, c 11 [Charter]. See Part II.B.1 below for further discussion of the Charter's impact on the open court principle.

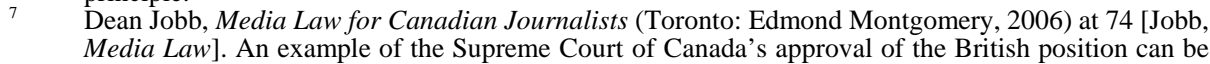
found in Attorney General of Nova Scotia v MacIntyre, [1982]1 SCR 175 at 186 [MacIntyre], citing Halsbury's Laws of England, 4th ed, vol 10 (London: Butterworths, 1973) at 316: "In general, all cases, both civil and criminal, must be heard in open court, but in certain exceptional cases, where the administration of justice would be rendered impracticable by the presence of the public, the court may sit in camera." As quoted in MacIntyre, ibid at 183. This passage has also been cited in Scott v Scott, [1913] AC 417 (HL) at 477 [Scott], amongst other cases.
(1909), 41 SCR 339 at 359, citing $R v$ Wright, 8 TR 293 at 298.

Willard Z Estey, "Freedom of Expression vs. The Individual's Right to Privacy," (Speech delivered at the Empire Club of Canada, Toronto, 21 April 1994) in The Empire Club of Canada: Addresses 19931994 (Toronto: The Empire Club of Canada, 1994) 412 at 426. 
Although the principle of open justice is applicable to all court proceedings, whether civil or criminal, it carries with it a heightened importance in the criminal context, which will be the focus of this article. This translates to an even greater necessity of ensuring a criminal proceeding is truly open. In his text on the principle of open justice in the British legal system, Joseph Jaconelli outlines a number of reasons for the increased importance of open courts in the criminal context, including the notion that a public conviction may be more effective in deterring crime. ${ }^{11}$ Moreover, in the criminal context, a wrong is an offence against the entire community and, therefore, the public has a vested interest in witnessing the proceeding in which it is authoritatively determined whether the accused is innocent or guilty. ${ }^{12}$

If the general public is not able to be physically present in the courtroom as these decisions on innocence or guilt are made, nor sit through lengthy trials as evidence is tendered and witnesses are examined, the open court principle is of little consequence. This is where the media comes in. Dean Jobb describes the media's role within the open court system as a dual one - a watchdog and an informer. ${ }^{13}$ The majority of the general public does not have the time or ability to attend trials and, even if they did, Canadian courtrooms cannot physically accommodate everyone who may have an interest in a particular proceeding. Thus, the public's right to have access to the courts must be exercised in another manner - "the public must rely on the media to be its eyes and ears." ${ }^{14}$ Canadian courts have recognized that the open court principle cannot be fulfilled in the absence of media access to the justice system. In Edmonton Journal $v$ Alberta (AG), Justice Cory emphasized the importance of the media's role in informing the public about the happenings of court:

\footnotetext{
It is exceedingly difficult for many, if not most, people to attend a court trial. Neither working couples nor mothers or fathers house-bound with young children, would find it possible to attend court. Those who cannot attend rely in large measure upon the press to inform them about court proceedings - the nature of the evidence that was called, the arguments presented, the comments made by the trial judge - in order to know not only what rights they may have, but how their problems might be dealt with in court... Discussion of court cases and constructive criticism of court proceedings is dependent upon the receipt by the public of information as to what transpired in court. Practically speaking, this information can only be obtained from the newspapers or other media. ${ }^{15}$
}

Like the importance of the open court principle more generally, the invaluable role the media plays in fulfilling that principle has been recognized countless times in courtrooms across the country. Justice Menzies eloquently summed up the general position of Canadian courts in $R v C T V$ Television Inc: "Media access to the courts is fundamental to our system of justice. In order for the justice system to engender the respect and confidence of society, it must be open to public scrutiny. Society must have access to court proceedings to be able to monitor, understand and in appropriate circumstances criticize the court system."16 The importance 2002) at 46-47, citing RA Duff, Trials and Punishments (Cambridge: Cambridge University Press, 1986) at $147-48$.

Ibid.

Jobb, Media Law, supra note 7 at 74-75.

Ibid at 75 .

[1989] 2 SCR 1326 at 1339-40.

2005 MBQB 143, 196 Man R (2d) 150 at para 5 [CTV]. 
of the open court principle and the correlating right of the media to access the justice system on the public's behalf has been firmly established in Canadian jurisprudence, building on the British tradition. To discuss how those rights actually play out in the courtroom, the role of the Charter, the Criminal Code ${ }^{17}$ and recent Supreme Court jurisprudence will now be discussed.

\section{B. The LAW AND THE OPEn Court PRINCIPLE}

\section{SECTION 2(B) OF THE CHARTER}

The enactment of the Charter did not create the open court principle or the correlating right of media access to the courts, but it did affirm and enshrine the same rights and values espoused by the concept of open justice. Section 2(b) of the Charter, with its guarantee of "freedom of thought, belief, opinion and expression, including freedom of the press and other media of communication," 18 has continued the long-standing tradition of the open court principle, sharing "the same underlying democratic values of free speech — for the purpose of scrutinizing government - that were articulated in the eighteenth and nineteenth centuries."19 Since the advent of the Charter, the courts have consistently held that the historical open court principle now has a firm footing in the freedoms set out in section 2(b). For example, in Toronto Star, Justice Fish stated:

That lesson of history is enshrined in the Canadian Charter of Rights and Freedoms. Section 2(b) of the Charter guarantees, in more comprehensive terms, freedom of communication and freedom of expression. These fundamental and closely related freedoms both depend for their vitality on public access to information of public interest. What goes on in the courts ought therefore to be, and manifestly is, of central concern to Canadians. $^{20}$

Moreover, the necessary link between the Charter, the open court principle, and the media was clearly stated by Justice La Forest in Canadian Broadcasting Corp v New Brunswick (AG), when he held that "s. 2(b) protects the freedom of the press to comment on the courts as an essential aspect of our democratic society.... As a vehicle through which information pertaining to these courts is transmitted, the press must be guaranteed access to the courts in order to gather information." 21

This is not to say that the post-Charter right of media access to the courts has proved to be absolute. Judges have, and use, the power to impose restrictions on media access in order to protect other interests. In particular, limitations on access will be considered when another Charter-enshrined right — namely, the right of an accused person to a fair trial — is at issue. ${ }^{22}$ Although it is possible for the guarantee of freedom of expression and the right to a

RSC 1985, с C-46.

Supra note 6, s 2(b).

Paul B Schabas, "Media Freedom under the Charter" in The Law Society of Upper Canada, Special Lectures 2001: Constitutional and Administrative Law (Toronto: Law Society of Upper Canada, 2002) 441 at 449.

Toronto Star, supra note 2 at para 2.

[1996] 3 SCR 480 at 498.

See Charter, supra note 6, s 11(d): “Any person charged with an offence has the right ... to be presumed innocent until proven guilty according to law in a fair and public hearing by an independent and impartial tribunal.” 
fair trial to be aligned in a given case, as media access allows for public scrutiny and comment on the issue of trial fairness, more often than not, these two Charter rights are seen to conflict. In such circumstances, the courts have made it clear that a "hierarchical approach to rights ... must be avoided." 23 In other words, no one right will automatically take precedence over another; the rights must be appropriately balanced in light of all the circumstances. Thus, while the media's right to access the courts has arguably been strengthened as a result of the Charter, so too have other, sometimes competing, rights.

\section{a. Relevant Criminal Code Provisions}

The focus of this article is the inherent jurisdiction of the court, as developed in the common law, to deny media access to various aspects of court proceedings - specifically access to exhibits. However, it is important to note that the Criminal Code also deals with media access in specific circumstances. Sections 486.4, 486.5, and 486.6 set out the process for a prosecutor, victim, witness, or justice system participant to apply for a publication ban. While the sections do not specifically deal with media access to court exhibits, it is worth mentioning that the factors set out in section 486.5(7) for the court to consider when determining whether or not to order a publication ban are similar to those employed under the common law in regard to both publication bans and other restrictions (such as those regarding exhibits) on the open court process. $^{24}$

\section{b. Case Law - Supreme Court of Canada Trilogy}

The common law framework for exercising judicial discretion regarding media access in Canadian courts has been outlined by the Supreme Court of Canada in a trilogy of cases: Dagenais $v$ Canadian Broadcasting Corp ${ }^{25} R v$ Mentuck, ${ }^{26}$ and Toronto Star. ${ }^{27}$ The foundational test for questions of whether the media's freedom of expression should be limited was set out in Dagenais, a case in which the four applicants were members of a Catholic religious order, charged with the physical and sexual abuse of young boys in their

See Dagenais v Canadian Broadcasting Corp, [1994] 3 SCR 835 at para 72 [Dagenais], where Chief Justice Lamer rejected a hierarchical approach to rights:

It would be inappropriate for the courts to continue to apply a common law rule that automatically favoured the rights protected by s. 11(d) over those protected by s. 2(b). A hierarchical approach to rights, which places some over others, must be avoided, both when interpreting the Charter and when developing the common law. When the protected rights of two individuals come into conflict, as can occur in the case of publication bans, Charter principles require a balance to be achieved that fully respects the importance of both sets of rights.

24 See Adrienne Roy, “R. v. Cairn-Duff: A Look into Media Access to Court Exhibits” (2009) 47:1 Alta

L Rev 257 at 266, where it is noted that section 486.5(7) is "very comparable to the jurisprudential test." The factors in section 486.5(7) are:

(a) the right to a fair and public hearing; (b) whether there is a real and substantial risk that the victim, witness, or justice system participant would suffer significant harm if their identity were disclosed; (c) whether the victim, witness or justice system participant needs the order for their security or to protect them from intimidation or retaliation; (d) society's interest in encouraging the reporting of offences and the participation of victims, witnesses and justice system participants in the criminal process; (e) whether effective alternatives are available to protect the identity of the victim, witness, or justice system participant; (f) the salutary and deleterious effects of the proposed order; (g) the impact of the proposed order on the freedom of expression of those affected by it; and (h) any other factor that the judge or justice considers relevant.

Supra note 23.

2001 SCC 76, [2001] 3 SCR 442 [Mentuck].

Supra note 2. 
care. The four accused applicants sought an order prohibiting the broadcast of The Boys of St Vincent, a television miniseries, which, although fictional, was similar to the facts in the applicants' trials. The applicants sought the order on the basis of the court's jurisdiction under the common law to order a publication ban, arguing that such a ban was necessary to protect their right to a fair trial.

In an effort to give due regard to the accuseds' right to a fair trial, while at the same time recognizing the Charter guarantee of freedom of expression, Chief Justice Lamer developed a new test to determine whether a common law publication ban should be ordered. Chief Justice Lamer held that a ban should only be ordered if:

(a) such a ban is necessary in order to prevent a real and substantial risk to the fairness of the trial, because reasonably available alternative measures will not prevent the risk; and

(b) the salutary effects of the publication ban outweigh the deleterious effects to the free expression of those affected by the ban. ${ }^{28}$

In the second case of the trilogy, Mentuck, the Court followed and affirmed the Dagenais test, but broadened it slightly. In Mentuck, the Court was again faced with an application for a publication ban, this time concerning evidence that was entered in a second degree murder trial and was obtained as a result of a Royal Canadian Mounted Police (RCMP) undercover operation. Due to concern over potential harm to the ongoing operation and, specifically, to the undercover officers still in the field, the Court decided to order a time-limited ban with respect to the officers' identities only. In doing so, the Court held that explicit consideration should be given to "the interests involved in the instant case and other cases where such orders are sought in order to protect other crucial aspects of the administration of justice."29 Thus the Court modified the Dagenais test, formulating what has become known as the Dagenais/Mentuck test:

A publication ban should only be ordered when:

(a) such an order is necessary in order to prevent a serious risk to the proper administration of justice because reasonably alternative measures will not prevent the risk; and

(b) the salutary effects of the publication ban outweigh the deleterious effects on the rights and interests of the parties and the public, including the effects on the right to free expression, the right of the accused to a fair and public trial, and the efficacy of the administration of justice. ${ }^{30}$

Another important aspect of the Mentuck decision was the Court's emphasis on the nature of the risk identified in the first step of the test. Justice Iacobucci held that, in order to preserve the highly valued principle of open and uncensored courts, the risk identified must be a "real and substantial' risk." 31 Put another way, Justice Iacobucci stated that "it is a serious danger sought to be avoided that is required, not a substantial benefit or advantage 
to the administration of justice sought to be obtained" in order to meet the first step of the test. $^{32}$

The third case in the Supreme Court trilogy, Toronto Star, dealt with a different aspect of media access. While Dagenais and Mentuck both involved common law publication bans, Toronto Star involved an application to quash an order sealing search warrants. The Court expanded the Dagenais/Mentuck test by applying it to the facts at hand and holding that the test is not only applicable to publication bans, but also "to all discretionary court orders that limit freedom of expression and freedom of the press in relation to legal proceedings."33 Justice Fish also reiterated the finding in Mentuck that the risk at issue must be a serious one, holding that a "generalized assertion" of an effect on the administration of justice is not enough to deny media access. ${ }^{34}$ In addition, the decision in Toronto Star made it clear that the Dagenais/Mentuck test is "meant to be applied in a flexible and contextual manner"35 and, importantly, confirmed the holding in Dagenais that the party seeking to limit freedom of expression bears the onus of justifying the limitation. ${ }^{36}$

This trilogy of Supreme Court cases appears to make the common law test for discretionary orders involving media access quite clear. In particular, the holding in Toronto Star that the Dagenais/Mentuck test encompasses all discretionary orders regarding limits on freedom of the press undoubtedly contemplates media-related discretionary orders outside the realm of the publication bans and warrant sealing orders dealt with in these three cases.

This is consistent with the historical position that the open court principle extends to court exhibits. In fact, the right of access to all facets of criminal and civil trials, including pleadings, indictments, transcripts, rulings, and exhibits, dates back to a fourteenth century British statute, which "granted 'any subject' the right to access the 'records of the King's Courts ... for his necessary use and benefit." 37 The rationale for this tradition of access to court exhibits is the same as that given for the open court principle more generally. In fact many would argue the publication or broadcast of exhibits is what truly enables the media to bring the court proceedings to the general public. According to Jobb: "Journalists need access to exhibits in order to properly cover court proceedings.... The publication of police photos or the broadcast of a videotaped interrogation conveys the reality of crime and investigative methods in a way that a written description cannot match." ${ }^{38}$ However, despite the modern value of court exhibits to the public via the media, the historical willingness to include exhibits in the open court principle, and the seemingly clear reiteration of a single test for all freedom of the press-related discretionary orders in Toronto Star, courts across the country have not been consistently or correctly applying the Dagenais/Mentuck test to questions of access to exhibits.

Ibid.

Toronto Star, supra note 2 at para 7 [emphasis in original].

Ibid at para 9 .

Ibid at para 8 .

Ibid at para 9; Dagenais, supra note 23 at 890.

Jobb, Media Law, supra note 7 at 237.

Ibid at 242. 


\section{WHAT DOES “OPEN COURT” MEAN TODAY?}

\section{A. INCONSISTENT DECISIONS}

Although there are relatively few cases on the specific issue of media access to court exhibits, the inconsistency and confusion regarding what the open court principle encompasses is evident in the jurisprudence and has, in fact, been noted by the courts themselves. For example, in the 2008 Alberta Court of Queen's Bench decision, $R v$ CairnDuff, ${ }^{39}$ the Court held that the case law does not make it clear what "access" to the courts includes. ${ }^{40}$ The Saskatchewan Court of Queen's Bench also commented on the widely varying decisions on questions of media access to court exhibits in its 2009 decision in $R v$ Casement, ${ }^{41}$ where it noted that "[n]otwithstanding the presumption of access to judicial records, the reported cases in this area of the law include decisions resulting in no access being given to the media, full access being given to the media, including the right to make copies and reproduce the exhibits, as well as decisions that can be described as hybrid providing access with restrictions." 42 These cases and others, discussed in more detail below, clearly illustrate the discrepancies in the case law. First, recent cases denying media access will be discussed, followed by cases granting access. Finally, common patterns and trends emerging from the jurisprudence will be outlined.

\section{CAses DenYing AcCess}

The Supreme Court of Canada decision in Vickery v Nova Scotia Supreme Court (Prothonotary) $^{43}$ is a fitting place to begin a discussion of the cases denying the media access to exhibits. Vickery is a pre-Dagenais decision of the Supreme Court, but unlike Dagenais, Mentuck, and Toronto Star, the decision deals directly with access to court exhibits, rather than to publication bans or warrant sealing orders.

Vickery dealt with a media application for access to electronic tapes admitted as evidence in a second degree murder trial. The accused was found guilty at trial, but the conviction was overturned on appeal. The media application followed the appeal decision. The majority of the Court denied the media's request, holding that the privacy interests of the (now innocent) accused outweighed the interest of the public in having access to the exhibits. In denying the request, the majority of the Court held that in a case like this, where the recordings in question were found to be inadmissible on appeal, courts must be especially careful in granting applications for access to "material which was found to have been obtained in violation of [the accused's] fundamental rights." 44 The Court then outlined a number of

2008 ABQB 576, 468 AR 117 [Cairn-Duff].

Ibid at paras 14, 17.

2009 SKQB 105, 330 Sask R 274 [Casement].

Ibid at para 39.

[1991] 1 SCR 671 [Vickery].

Ibid at 685. It is important to note that the inadmissibility of the recordings in this case distinguishes Vickery from the majority of the cases discussed in this article. Generally, the cases involving media applications for access to exhibits are ones in which admissibility is not an issue and thus the same type of concerns regarding any alleged violation of the accused's fundamental rights are not relevant. Moreover, as argued by the dissent in Vickery (discussed below), even where admissibility of evidence is an issue, that is not necessarily a valid reason for denying access. 
factors that should be taken into consideration when determining whether to permit media access to exhibits: ${ }^{45}$

(1) the nature of the exhibit, for example, whether it is a court record or the property of a non-party;

(2) the court's right to inquire into how the exhibit will be used;

(3) the fulfilment of the open court requirement, which was held to already have been met here through the production of the exhibits at trial ${ }^{46}$; and

(4) the issues surrounding non-contemporaneous public scrutiny, which was found to be an issue here as the exhibits would be played outside the context of the courtroom. ${ }^{47}$

The majority of the Court held that it was not necessary to grant the media access to the exhibits as allowing the pubic access to the courtroom during proceedings was sufficient to meet the open court principle. The Court also held that once an exhibit has played its role in the trial, there is no longer a need for contemporaneous scrutiny of the justice system. ${ }^{48}$

However, there was a strong dissent in Vickery, which favoured a much broader interpretation of the open court principle. ${ }^{49}$ The dissent held that there is a clear common law right in Canada of open access to court documents and disagreed with the majority's contention that the open court principle was met simply by playing the tapes in court. ${ }^{50}$ In fact, the dissent held that the case for providing access to the tapes was actually strengthened by the fact that they had already been played in open court as the privacy interests were now rendered "less compelling." ${ }^{1}$ In justifying its finding that the tapes should have been released, the dissent also emphasized the increased importance of the open court principle since the advent of the Charter. Finally, the dissent took issue with the majority's reliance on the inadmissibility of the evidence in question as a reason for denying access, arguing instead that the public, through the media, had the right to know what evidence had been excluded and why. It is also of note that the only justice still sitting on the Court, Chief Justice Beverley McLachlin, was part of minority in Vickery. ${ }^{52}$

It would appear that Vickery has been superseded by the Supreme Court's decisions in Dagenais, Mentuck, and Toronto Star, as the Vickery factors were not incorporated into the Court's analysis in those cases and the Court clearly stated that the new test applies to all discretionary orders limiting freedom of the press. The very recent British Columbia

As summarized in $R v$ Schoenborn, 2010 BCSC 40, [2010] BCJ no 46 (QL) at para 46 [Schoenborn]. Vickery, supra note 43 at 683.

Ibid at 684. The Court was also concerned that the "release and publication of selected exhibits is fraught with risk of partiality, with a lack of fairness” (ibid at 685).

See David Crerar \& Majda Dabaghi, "SCC Upholds Open Court Principle for Media Reporting on Proceedings,” The Lawyers Weekly 25:4 (28 October 2005) 15.

The Court in Vickery, supra note 43, was split 6-3.

Ibid at 701, 708 .

Ibid.

See Crerar \& Dabaghi, supra note 48 at 15. 
Supreme Court decision in Schoenborn ${ }^{53}$ relied heavily on the Vickery analysis, suggesting that the case still applies where the issue is access to court exhibits. In Schoenborn, the Canadian Press and the Canadian Broadcasting Corporation (CBC) applied for access, for the purpose of broadcast, to two audio tapes played in open court. The accused was charged with first degree murder of his three infant children, and the tapes contained conversations recorded by the RCMP between the accused and the children's mother. The Crown and Defence opposed the media's application, arguing the mother's privacy rights would be compromised and she would suffer further hardship. However, no evidence was tendered by either the Crown or Defence as to the alleged hardship or the issue of whether such harm was real and serious, rather than speculative. In the result, the Court denied the media access to the exhibits, holding that submissions from counsel who had spoken with the mother were evidence enough. ${ }^{54}$

The Court did cite the Dagenais/Mentuck test, noting that it "applies to all discretionary orders limiting the open court principle." ${ }^{55}$ However, the Court then essentially relied on the old authority of Vickery, emphasizing that the open court principle was not diminished due to the opportunity the media already had to listen to the recordings in court, and the fact that the media themselves could listen to those recordings again if they so wished. The Court justified its reliance on the Vickery decision on the basis of a statement by Justice Fish in Toronto Star, where he referred to "an unbroken line of authority in this Court over the past two decades." 56 The Court in Schoenborn reasoned that because Vickery had been decided in the two decades prior to Toronto Star, it was still good law and should be applied. This reasoning is weak and unsatisfactory. The Court in Toronto Star was careful to re-articulate and affirm the Dagenais/Mentuck test and was clear that the test should now be applied to all discretionary orders involving restrictions on freedom of the press. If the Court had wanted to incorporate the factors in Vickery into the new Dagenais/Mentuck test it could have explicitly done so.

In addition, there are other problems with the Court's analysis in Schoenborn. Even if harm had been shown on the evidence presented, the Court should still have considered whether there were other means to address that harm short of denying access altogether. The Court here was not open to such alternatives, refusing to release the exhibits even with the wife's voice redacted. ${ }^{57}$ Moreover, in relying on Vickery, the Court did not address the significant discrepancies in the facts between the two cases. Vickery dealt with a video, which had been ruled inadmissible, of an accused who had already been acquitted of all charges, and no Charter arguments were advanced or considered by the Court. These facts were very different from those before the Court in Schoenborn. While valid privacy concerns existed with respect to the wife in this case, those concerns would have arguably been properly dealt with under the second step of the Dagenais/Mentuck analysis, rather than through reliance on the now dated decision in Vickery. 
Therefore, although the statement in Toronto Star that the Dagenais/Mentuck test applies to all discretionary media issues appears to suggest that Vickery is no longer good law, there are decisions like Schoenborn which suggest this is not the case. ${ }^{58}$ Moreover, it must be conceded that while the Court in Toronto Star did not explicitly incorporate Vickery into the Dagenais/Mentuck test, neither did it clearly overrule it. However, it was suggested by the British Columbia Supreme Court, in a case pre-dating Schoenborn, that Vickery is not actually incompatible with the Dagenais-Mentuck-Toronto Star line of cases: "Given the test set out in Toronto Star and the statement of the court that the Dagenais/Mentuck test must be applied flexibly and contextually, it should not be difficult to incorporate the considerations with respect to exhibits from Vickery into the exercise of discretion as to the release for reproduction of a particular exhibit." ${ }^{\text {"I }}$ In fact, it is likely possible to go one step further, and argue that while the Vickery decision has not been explicitly overturned, the application of the factors it sets out has become unnecessary as they encompass the same considerations laid out in the Dagenais/Mentuck test.

Aside from Schoenborn, a handful of other recent cases have continued to cite Vickery when addressing questions of media access to exhibits, but the Vickery factors are generally used in support of considerations already present in the more modern test. For example, in $R v$ Sylvester (Re Canadian Broadcasting Corp), the Court cited Vickery when holding that it was 'required to balance the applicants' interest, the public interest, [the accused's] and the community's fair trial interests as well as any privacy interests at the time access is sought." ${ }^{60}$ However, these concerns are all encompassed in the two-part Dagenais/Mentuck test, which requires a balancing of these interests. ${ }^{61}$ Furthermore, even some of the more potentially problematic aspects of the Vickery test, such as concerns regarding noncontemporaneous scrutiny, can be dealt with in the Dagenais/Mentuck framework in that they could be found to present a "serious risk" to the administration of justice or outweigh the importance of freedom of expression. Thus, whether or not Vickery is still good law, it can be effectively argued that the factors it sets out would not change a court's analysis under the Dagenais/Mentuck test.

There are other post-Dagenais decisions dealing with access to exhibits which do not improperly rely on Vickery, but nevertheless fail to correctly apply the Dagenais/Mentuck test. In Casement, the CBC, CanWest, and CTV applied to the Saskatchewan Court of Queen's Bench for an order allowing them access, for broadcast and print purposes, to audio and video recordings of conversations from an undercover operation involving the accused. The application, made after a jury found the accused guilty of first degree murder, was opposed by the Crown, the Defence, and the RCMP undercover officers. The Court cited the Dagenais/Mentuck test, but then went on to say the applicants were wrong to frame their request as an open court issue because it had "nothing to do with the openness of the

Another post-Dagenais/Mentuck case regarding access to exhibits is $R v$ Grewall, 2000 BCSC 1373, 48 WCB (2d) 208. The Court did not apply the Dagenais/Mentuck test, but instead held that Vickery is the leading case in this area (ibid at para 21). $R v$ Black, 2006 BCSC 2040, 74 WCB (2d) 441 at para 19 [Black]. This case will be discussed in further detail below.

(2007), 222 CCC (3d) 106 (Ont Sup Ct J) at para 69 [Sylvester].

61 The second part of the Dagenais/Mentuck test requires a weighing of the salutary and deleterious effects "on the rights and interests of the parties and the public, including the effects on the right to free expression, the right of the accused to a fair and public trial, and the efficacy of the administration of justice,” Mentuck, supra note 26 at para 32; see also supra note 32 and accompanying text. 
Court."62 The Court held that, at the time of the application, the open court principle was already fulfilled as the trial was open to the public, the applicants had been present in the courtroom during that trial, and the applicants were permitted to report whatever they deemed appropriate, subject to a narrow publication ban ordered in the case. ${ }^{63}$ The Court reasoned that the extensive editing of the exhibit that would surely be done by the media would result in the broadcast of something "not conducive to the proper administration of justice." ${ }^{64}$ In the result, the Court allowed the applicants to view the exhibits, but not to copy them for broadcast purposes.

The Court's decision in Casement that the requirement for open justice is met simply by allowing the media to be present during proceedings and to report on what they are able to see and hear in the courtroom, espouses a narrow view of the open court principle. Due to its acceptance of this narrow interpretation of open justice, the Court was prevented from properly considering and applying the Dagenais/Mentuck test. As such, no valid reasons were given as to how providing full access to the exhibits would present a "serious risk" to the administration of justice, nor was there a consideration of how such access would impact the applicants' freedom of expression or the accused's right to a fair trial. The Court's concern over the media's potential editing of the exhibits is also problematic as such reasoning improperly places the court in the shoes of a news editor. The open court principle must, and generally does, operate on the assumption that the media will engage in fair and accurate reporting, and it is not the judge's role to make a decision, in the absence of supporting evidence, that the media will act otherwise. The flawed reasoning in this case demonstrates that even where courts properly cite the Dagenais/Mentuck test as the test that should be applied to questions of media access to exhibits, it is still possible for improper considerations to cloud the decision, potentially resulting in an outcome that actually operates against the open court principle.

Another decision that appears to distort the Dagenais/Mentuck test is Sylvester, ${ }^{65}$ a second degree murder trial in which the CBC and Global Television applied for an order allowing them to copy DVDs containing statements made by the accused to police investigators. ${ }^{66}$ The statements included "a fulsome account of the killing itself, including a re-enactment of the physical struggle and beating," ${ }^{\prime 67}$ and were described by the Court as "the most crucial item of evidence the jury will hear." ${ }^{\text {" }}$ In denying the media’s application, the Court cited the Dagenais/Mentuck test but held, similarly to the decision in Casement, that the open court

This reasoning was also relied on in $R v$ Terezakis, 2006 BCSC 404, 78 WCB (2d) 327. In that case, CTV made an application for access to a compilation DVD containing exhibits that was filed and played in open court during a trial involving assault and unlawful confinement. The co-accused opposed the application, arguing that it "would prejudice his right to a fair trial, would violate the privacy of innocent third parties, and would infringe [his] proprietary interest[s]" (ibid at para 19). The Court denied the media's application, reasoning that the privacy rights of third parties must be protected and obscuring their images and voices was not an adequate solution (at paras 32, 48). The Court also supported its decision by holding that the open court principle was already fulfilled as the video evidence had been shown in open court. Casement, supra note 41 at para 57, quoting $R v$ Fry, 2008 BCSC 1485, [2008] BCJ no 2082 (QL) [Fry, $\mathrm{SC}]$ at para 22.

Supra note 60.

The Crown and the Defence opposed the media's application.

Sylvester, supra note 60 at para 25 . Also at issue was video footage of the site where the body was initially dumped and then later moved (ibid at para 28).

Ibid at para 33. 
principle was fulfilled by the fact that "[t]he entire content of all recordings, audio and video, either has been or will be played in the courtroom before the jury" with no restrictions on publication. ${ }^{69}$ Thus, the Court did not find that its decision impacted the openness of court - rather, the Court characterized the issue at hand as a question of "how the court should exercise its discretion in relation to the format of the information to be disseminated, not the content." ${ }^{\text {"70 }}$ The Court further supported its decision to deny access by holding that the dissemination of video evidence would have a "fundamentally different" impact on the public than media reporting via the printed word, particularly given the Court's finding that the media would choose to broadcast only the most sensational elements of the video exhibit. ${ }^{71}$ Based on these conclusions, the Court held that the video evidence was potentially inflammatory and carried with it a "real possibility" of adversely impacting the fair trial rights of the accused. ${ }^{72}$ The Court made these findings solely on the basis that "[t]he trial judge is in a good position to assess the impact of publicity in the context of the issues and the evidence presented."73 In fact, no evidence at all was presented with regard to these potential negative effects of allowing access to the exhibit.

Although this decision cites the Dagenais/Mentuck test, it essentially disregards it in favour of "common sense" reasoning and a form of judicial notice regarding the impact on the public of media access to exhibits. The Court offers no evidentiary basis for its assumption that the media will present only sensational portions of the exhibit and provides no link as to how this presumed tendency to sensationalize material will negatively impact the accused's fair trial rights. While the Court mentions the Dagenais/Mentuck test, it does so almost in passing, replacing its key components with the Court's own unfounded assumptions. Moreover, through taking judicial notice of the negative implications of allowing access to the exhibit, the Court reverses the burden set out in the Supreme Court trilogy and incorrectly places the onus on the media to demonstrate why access should be allowed.

In the cases outlined in this section thus far, the courts have cited the Dagenais/Mentuck test, but have either applied it improperly or essentially ignored it by relying on other considerations. However, there are other recent cases involving media access to court exhibits that are even more troubling because there is no attempt whatsoever to apply the Dagenais/Mentuck test. This was the case in the Ontario decision in $R v$ Ranger, ${ }^{74}$ which dealt with an application by CityTV for access for broadcast purposes to video exhibits in a first degree murder trial. In denying CityTV’s application, the Ontario Court of Justice

$69 \quad$ Ibid at para 70.

$70 \quad$ Ibid at para 72 [emphasis in original]. This characterization was followed by the Alberta Court of Queen's Bench in Cairn-Duff, described in detail below.

Ibid at para 77.

Ibid at para 81 .

Ibid at para 85. In coming to this conclusion, the Court distinguished the instant case from Hogg, supra note 4 (to be discussed in detail in Part IV.A, below). In Hogg, the Manitoba Court of Appeal overturned a lower court decision on the basis that it was decided on the same type of reasoning, with no evidentiary basis, as seen here. However, the Court in Sylvester found that the two situations were not analogous because in Hogg, the judge's conclusions were found to be lacking in evidentiary support in relation to whether the release of the exhibit would have any impact on the police process of taking statements and the tendering of those statements as evidence, whereas here, the Court was considering the impact of publicity more generally (ibid at paras 83-85).

74 (1998), 40 WCB (2d) 230 (Ont Ct J (Gen Div)) [Ranger]. 
failed to even mention Dagenais, ${ }^{75}$ instead relying on completely novel and unsubstantiated considerations, holding that

the accused's right to a fair trial and the legitimate privacy rights of any witness or even non-witness must be protected from undue sensationalism. After all, written words tend to be more rational and less evocative than pictures or film. Pictures and film often evoke immediate visceral response whereas words generally require refection and assessment. The public seeing the pictures or film lack the calm serenity of a courtroom and the limiting instruction the trial judge gives the jury as to the use to be made of the pictorial exhibit. ${ }^{76}$

The Court also held that the legal burden in this type of case is on the media applicant "to justify why a particular exhibit requires pictorial publication and why that form of publication outweighs the accused's right to a fair trial having regard to potential prejudice to the accused or the privacy right of any other individual," onus set out in Dagenais.

Ranger can arguably be distinguished from the other decisions discussed in this article because the applicant was requesting access to all exhibits, rather than making a more specific application. However, regardless of that fact, the Court's reasoning completely disregards the open court principle. Rather than applying the test set out in Dagenais, or even using any type of principled or evidence-based reasoning, the Court employs the same type of "common sense" approach seen in other problematic decisions in this area. Moreover, the judge unduly elevates the accused's right to a fair trial over the guarantee of freedom of expression, instead of properly balancing any potentially conflicting rights.

In Cairn-Duff, ${ }^{78}$ the Alberta Court of Queen's Bench explicitly chose not to apply the Dagenais/Mentuck test to the issue of access to exhibits. In this case, the CBC made an application for a copy of an audiotape recording of an Emergency Medical Services call entered as an exhibit in a second degree murder jury trial. The Court referred to the Dagenais/Mentuck test, but distinguished it from the case at hand because it dealt with an application by the media, whereas Dagenais and Mentuck both involved "an application by the Crown or the Defence to limit information that would be available to the press." ${ }^{\text {"79 }}$ Citing Sylvester, the Court framed the issue not as whether the media was entitled to access, but whether the media was entitled to access the exhibit in the exact format in which it was presented in court. Moreover, the Court held that the onus of establishing this entitlement was on the party making the application for access. ${ }^{80}$ The Court ultimately denied the CBC's application on the basis that media access to the audiotape for broadcast would have "a negative impact on the public's measured response to the Accused." 81 The Court also held that the open justice requirement was met despite the Court's decision to deny access because "the courtroom was open to the public when the audiotape was played for the jury," there was "[n]o publication ban," and the media were "at liberty to report fully on the contents of

Dagenais had been decided four years earlier; Mentuck had not yet been decided.

Ranger, supra note 74 at para 5.

Ibid at para 7.

Supra note 39.

Ibid at para 36 [emphasis in original].

Ibid at para 73.

Ibid at para 43. 
the recording, just as they could have reported on the proceeding in Court."82 Finally, the Court raised a number of practical concerns with granting the release of the exhibit: "[i]f openness extends to the format for exhibits, then courts across this country will be obligated to establish means by which the media can obtain the evidence in the format it was presented in court." 83 The Court suggested that there is currently no appropriate process for providing the media with a particular exhibit and any possible system would be fraught with difficulties. ${ }^{84}$

The decision in Cairn-Duff is problematic on a number of fronts. Most troublesome is the finding that the Dagenais/Mentuck test is not applicable to media requests for access to exhibits, despite the clear statement in Toronto Star that the test "applies to all discretionary court orders that limit freedom of expression and freedom of the press in relation to legal proceedings." 85 Also worrisome is the narrow interpretation of the open court principle exhibited by the Court's reasoning that the principle was met simply by playing the recording in open court. Furthermore, the holding regarding the "impact on the public's measured response to the accused" is not equivalent to finding the accused's fair trial rights will be implicated and thus is irrelevant under a proper application of the Dagenais/Mentuck test. It is also problematic that, as in Ranger, the onus is improperly placed on the media to justify an order permitting access. Finally, while there may well be some practical concerns in facilitating media access to court exhibits, the Cairn-Duff decision appears to exaggerate the potential issues. Although the Court cites potential problems with the process of providing media access as one of the key reasons in its decision to deny access, the issues to which she refers - such as who is responsible for copying the exhibit and who will bear the cost - are far from insurmountable. In fact, in the cases where media access is permitted, this "problem" appears to be a non-issue, or at least one that can be addressed without much difficulty. Where media access to exhibits is granted, courts generally order that the integrity of the tape be maintained and that care be taken to ensure the exhibit is not damaged. ${ }^{86}$

82
83 $\quad$ Ibid at para 86.

84 The Court suggested four possibilities:

1. The exhibit is given to the media for the purpose of copying;

2. The media brings into the courtroom under the supervision of court personnel its equipment to copy the exhibit;

3. The party whose exhibit it is provides a copy; or,

4. The Court provides a system for and personnel to provide copies to the media.

Ibid at para 47. The Court had serious concerns with all of these options, stating that the first option means continuity of the exhibit is lost, the second and fourth possibilities involve using taxpayer money to facilitate the process, and the third option unduly puts the costs burden on the litigants (ibid at para 48).

85 Toronto Star, supra note 2 at para 7.

$86 \quad$ See e.g. Hogg, supra note 4 at para 47, where Justice Monnin makes his final order: "I would therefore allow the appeal and order that the appellant is entitled to have access to and copy the videotape subject to any condition the court officers may impose to preserve the integrity of the exhibit.” In CTV, supra note 16 at para 14, the Court's order allowing the media access to the exhibits was made "subject to safeguards being taken to ensure the preservation of the integrity of the recordings and to ensure that no damage is caused to the recordings during the course of reproduction.” In $R v$ Van Seters (1996), 31 OR (3d) 19 (Ct J (Gen Div)) [Van Seters] at 21, the Court held, "recognizing the requirement of preservation of the integrity of the tape, that the video-tape exhibit can and should be released for duplication ... subject to appropriate safeguards undertaken by the Registrar of the Court to ensure the integrity of the tape and that no damage is caused during the course of the reproduction.” In Black, supra note 59 at para 63, where the media was allowed access to video exhibits for the purpose of copying and broadcast, subject to the condition that the identity of undercover officers and third parties be protected, the judge ordered that the media be given the tapes to copy and then to conceal the identities as ordered (through blurring etc). Once the identities had been concealed, the media was to send the tape for approval to the other relevant parties (RCMP, Crown, and Defence). Upon approval the media could 
Concerns about such matters are valid and should be addressed, but this can be done, as the decisions where access is granted have demonstrated, in a manner that does not curtail the open court principle or freedom of expression. The concerns expressed by the Court are therefore not significant enough in themselves to offset the importance of open justice and, as such, are not relevant considerations within the context of the Dagenais/Mentuck test.

\section{CASEs GRANTING ACCESS}

During the same time period in which the decisions outlined above were resulting in the media being denied access to court exhibits, often on the basis of faulty reasoning and/or a misapplication or ignorance of the Dagenais, Mentuck, and Toronto Star decisions, other cases were being decided in a manner that gave greater weight to the importance of the open court principle and properly interpreted the Supreme Court jurisprudence. These decisions, perhaps unsurprisingly, often resulted in the granting of media access to court exhibits.

An example of one such case is $C T V,{ }^{87}$ a first degree murder trial in which the CBC and CTV applied for access for the purpose of broadcast to video and audio recordings of statements given by the accused to undercover police officers. The accused opposed the application, arguing that granting access would be a violation of his privacy and could adversely affect the administration of justice. ${ }^{88}$ However, after applying the Dagenais/ Mentuck test, the Court disagreed with the accused and ultimately granted access to the exhibits. Of note in this case is the Court's emphasis on the importance of including media access to exhibits in the open court principle, as the Court held that to deny a media application in a case such as this "would be tantamount to granting a ban on publication." 99 The Court thus rationalized the use of the same test for both access to exhibit applications and publication bans. In coming to its decision, the Court did what many judges in the cases outlined in the previous section failed to do: it properly assigned the onus as set out by the Supreme Court of Canada, holding that the burden of proof is on the one who opposes disclosure. Here, although the accused opposed the release of the exhibits, he failed to call any evidence in support of his position and, therefore, did not meet that burden. The Court also cautioned against another common trend in the cases discussed above - the propensity of judges to act as news editors. The Court held that "[c]ourts should be reluctant to restrict the media in the manner in which it reports on the processes before the courts," 90 thus suggesting that it is not for the courts to determine whether a story would be more properly told through a reporter's interpretation alone or through actual reproduction of a video exhibit or other evidence. This approach is consistent with the open court principle, which can only properly operate on the assumption that the media will report fairly and accurately. ${ }^{91}$ As such,

then broadcast that tape, and the master tapes were to be returned to counsel for the Attorney General of Canada. In the recent British Columbia Court of Appeal decision in Fry, supra note 5 at para 79, the majority made a disposition similar to that in Black. The Court of Appeal's conditions on the media's access to the exhibits included: the media are responsible for bearing the cost of copying the exhibits; the media must alter the exhibits to "protect absolutely the identities of the RCMP officers and the other individuals mentioned in the tapes to the satisfaction of the RCMP”; the media shall then provide the altered exhibits to RCMP and Crown counsel, who then have two weeks to notify the media of any concerns; and if any concerns cannot be resolved, they shall be referred to the Court.

CTV, supra note 16 .

Ibid at para 3 .

Ibid at para 4.

Ibid at para 13.

See discussion regarding Fry below. 
true freedom of the press, a historical and now constitutionally enshrined component of the open court principle, cannot be attained where a judge assumes the role of news editor.

The case of $R v$ Tarala $^{92}$ is another example of a court correctly applying the Dagenais/ Mentuck test to a media application for access to an exhibit. In Tarala, the CBC applied for access to a videotape entered into evidence at an assault trial in which the accused was an employee of a psychiatric centre and prison, where the alleged victim was a patient. The video depicted the victim alone in her cell, playing with her hair, colouring a blanket with a crayon, and then colouring the lens of the camera. ${ }^{93}$ The media made the application for the purpose of using the video in a documentary on "systemic problems that exist when people with mental issues, especially youth, end up in the correctional system." ${ }^{\text {"4 }}$ In deciding to grant the media's request, the Court concluded that there is a "presumption that all proceedings in Court, including the exhibits themselves are available to the press" and that, as per the Dagenais/Mentuck test, the presumption can only be rebutted "if there is a wellfounded and serious risk to the fairness of the trial, the privacy of affected individuals, or there is evidence of a serious risk of harm to the administration of justice." ${ }^{\text {,5 }}$ Here, it was argued by the psychiatric institution that the media's application should be denied on the basis that the release of the video would jeopardize the institution's security. The Court rejected this argument, finding that it was speculative at best, and, as held by the Supreme Court of Canada, "[s]peculation about a serious risk to the administration of justice is an insufficient basis for denying access to the exhibit."96

Another example of a correct application of the Dagenais/Mentuck test is $R v$ Black, ${ }^{97}$ a case in which the CBC and CHBC applied for permission to reproduce and broadcast audio and videotape from an RCMP undercover operation that had been entered as exhibits at trial. While the Court held that the protection of the identities of the undercover officers and third parties was important, it applied the Dagenais/Mentuck test and ultimately granted the media's application with the condition that any information identifying the officers or third parties be edited out. The decision in Black questioned a common argument accepted by courts in many of the cases denying media access - that the accused's right to a fair trial would be harmed by granting the media access to the exhibit in question. The Court held that in most cases, while the reproduction of exhibits would undoubtedly lead to increased public discussion and the voicing of differing views on the alleged offence, court process, and end result, such public debate does not negatively affect fair trial rights and "is the result of the important principle of accessibility to and openness of the courts." 98 The Court also echoed

$R v$ Tarala, 2009 SKPC 139, 349 Sask R 104 [Tarala].

Ibid at para 6.

Ibid at para 3.

Ibid at para 24

Ibid at para 20. $R$ v Côté (Re CanWest Media Works Inc), 2007 MBQB 40, 213 Man R (2d) 233, is another example of a court properly applying the Dagenais/Mentuck test. In this case, the media applied for access to a videotape exhibit for the purpose of broadcast. The video depicted the accused shooting the victim in a robbery attempt. The Crown argued that the application should be denied to protect the privacy of the victim's family; the media proposed to blur the victim's face (ibid at para 11). The Court applied the Dagenais/Mentuck test and held that "the Crown [had] not shown that an absolute ban in this case [was] necessary to prevent a serious risk to the administration of justice" and that the distortion of the victim's face would adequately protect the privacy issues of the family (ibid at para 17).

Supra note 59.

Ibid at para 26. It is important to note that Black was a judge-alone trial and there was no question as to the admissibility of the evidence in question (ibid at para 2). 
the holding in CTV that courts should refrain from acting as news editors, emphasizing that, as part of the guarantee of freedom of expression and freedom of the press, the media is entitled to edit material as they see fit, free from court control. ${ }^{99}$ Importantly, the Court also explicitly commented on what appears to be the unstated basis of many of the decisions denying media access: "[W]hat underlies the resistance to the production of the exhibits in this case is basically a distrust of the media's motives in reporting." ${ }^{\text {"100 }}$ Again, this inherent distrust of the media contradicts the necessary assumption of the open court principle that the media will report fairly on court proceedings.

Two other cases that are slightly more dated now, but which emphasize an important argument in favour of media access, are Van Seters ${ }^{101}$ and Stark. ${ }^{102}$ In Van Seters, City TV and The Toronto Star applied for access to a videotape depicting the accused police officer bringing the deceased into the police station. The videotape had been played before the jury in open court and members of the deceased's family had consented to the release of the exhibit. The Court applied Dagenais ${ }^{103}$ and ultimately allowed the media's application. The Court held that once the video was played in court it became part of the "public domain" and should be treated as public material. ${ }^{104}$ The public domain argument was also relied on in Stark, a case in which CTV applied for an order allowing it to view and copy a videotaped statement given to police by the accused. The videotape had been ruled admissible and played in open court at the accused's second degree murder trial. The Court cited Dagenais ${ }^{105}$ and, relying on the public domain argument, ultimately allowed the media's application with the condition that any reference to the co-accused, who was being tried separately, be edited out. The condition imposed by the Court in Stark is demonstrative of an appropriate balancing of the open court principle with the necessity of promoting the proper administration of justice. The approach in both Stark and Van Seters is consistent with the general rule that court proceedings are open. Then, as these cases demonstrate, once something has entered the "public domain" of the courtroom, access should only be denied where it "is necessary to prevent a serious risk to the proper administration of justice" and the salutary effects of denying access outweigh the deleterious effects. ${ }^{106}$

Ibid at para 32. This point was also emphasized by the Court in $R v$ Stark, [1995] BCJ no 3064 (SC) (QL) at para 18 [Stark], where Justice Lander cautioned courts who overstep their boundaries by trying to control the content of media reports, stating "the court cannot extend its writ to the cutting room." Black, ibid at para 28.

Supra note 86. In Van Seters, Justice Keenan also emphasized the important principle in cases of this nature, stating that " $\mathrm{t}]$ he privacy interest of the accused is not engaged ... as the expectation of privacy of one who is accused of a criminal offence and is before the court is, by that fact itself, considerably diminished" (ibid at 20). This is a frequently cited principle in cases where the accused opposes a media application for access by arguing that his or her privacy interests will be harmed. Supra note 99.

This case was decided prior to the decision in Mentuck.

Van Seters, supra note 86 at 21.

Dagenais had been decided at this time, but not yet reported.

As per the Dagenais/Mentuck test, cited above at note 30. A similar argument to that of the "public domain” was relied on by the Court in $R v$ Young, 2008 BCPC 215, [2008] BCJ no 1417 (QL), a decision allowing the media access to an audiotape of a 911 call played in open court during sentencing submissions in an assault case involving the mayor of Port Coquitlam. The Court rejected the same argument accepted many times in the cases denying media access — that the playing of the 911 audiotape in Court was adequate to fulfill the open court principle. 


\section{B. CONCLUSIONS}

The two groups of cases outlined above demonstrate that Canadian courts have been inconsistent in their treatment of media applications for access to court exhibits. However, while the inconsistencies are certainly stark as between the two broad categories of cases denying access and cases allowing access, there are definite patterns and trends within each group. In the cases denying media access, a number of common themes can be discerned. First, courts in this category often misinterpret, misapply, or even completely ignore the Dagenais/Mentuck test. ${ }^{107}$ This is despite the clear articulation of the test in the Supreme Court trilogy and the unequivocal statement in Toronto Star that the Dagenais/Mentuck test applies to all discretionary decisions regarding media access. Courts are not only basing their decisions on irrelevant considerations that are not properly part of the Dagenais/Mentuck test, but they are also reversing the onus clearly outlined in Dagenais. Instead of requiring the party opposing access to demonstrate why the media's application should be denied, courts are demanding that the media prove why access is necessary, even where no opposing evidence is tendered. ${ }^{108}$ A second and related reoccurring theme is that an alarming number of courts are relying on a "common sense" approach to reaching a decision. Rather than basing their decisions to deny media access on substantive evidence of prejudice to the accused's fair trial rights, infringement of a party's right to privacy, or a detrimental impact on the proper administration of justice, courts are all too often basing their conclusions on speculative assumptions that the media will sensationalize the material in question. ${ }^{109}$ A third common thread in the cases denying access is that courts have been overstepping their boundaries by effectively assuming the role of news editor through attempts to control what and how the media reports. ${ }^{110}$ This approach demonstrates a lack of respect for the principle that freedom of expression generally includes the media's ability to control the content it produces.

Common themes also emerge in the cases where media applications for access to exhibits have been granted. These trends essentially entail the opposite approach to that which is taken in the cases just discussed. For example, the courts in this category consistently applied the Dagenais/Mentuck test and disregarded the type of irrelevant considerations evident in many of the cases where access was denied. ${ }^{111}$ Moreover, the courts in these cases appropriately applied the onus to the party opposing the media application. ${ }^{112}$ In addition, the courts' decisions often include stark warnings about the dangers of the judiciary attempting to control the content produced by the media. ${ }^{113}$ Finally, the judges in these cases were more likely to grant media applications in part, allowing the media access to the exhibits on the condition that certain portions would be edited out, in order to protect third party interests and/or ensure the proper administration of justice. ${ }^{114}$

For cases that misinterpret or misapply the Dagenais/Mentuck test see e.g. Fry, SC, supra note 64; Casement, supra note 41. For cases that that do not apply the Dagenais/Mentuck test at all see e.g. Cairn-Duff, supra note 39; Ranger, supra note 74.

See e.g. Sylvester, supra note 60.

See e.g. ibid.

See e.g. Fry, SC, supra note 64; Casement, supra note 41.

See e.g. Black, supra note 59.

See e.g. CTV, supra note 16.

See e.g. CTV, ibid.; Black, supra note 59.

See e.g. Black, ibid. 


\section{WHAT SHOULD “OPEN COURT” MEAN TODAY?}

The inconsistencies between the two groups of cases appear to stem from divergent interpretations of where and how the right to access exhibits fits into the open court principle. While courts on one side have held that the open court principle encompasses full media "access to documents, records and exhibits," including "the duplication of electronically generated records, such as audio and video tapes," open court principle is fulfilled simply by permitting the media to be present during proceedings and to report on what they are able to see and hear in the courtroom. ${ }^{116}$ The question to be answered then is what does the open court principle actually entail? The previous discussion regarding the historical background of the open court principle and recent Supreme Court of Canada jurisprudence clearly suggests an interpretation consistent with that of the cases where access has been granted. The open court principle, as imported from the British tradition, has always been interpreted broadly, with restrictions on public access of any kind being the rare exception. ${ }^{117}$ It has also long been held that public access can only be effectively achieved through the media, and the media's right of access to the courts has gained strength through the enactment of the Charter, which now constitutionally protects freedom of expression and freedom of the press. ${ }^{118}$ Finally, the decisions of the Supreme Court in Dagenais, Mentuck, and Toronto Star have reiterated the importance of the open court principle and clearly articulated a test which only provides for restrictions in limited circumstances and after a careful weighing of all relevant factors.

\section{A. A MOdel APPROACH: $R$ V HogG AND $R$ V FRY}

The decisions of the Manitoba Court of Appeal in Hogg and the British Columbia Court of Appeal in Fry are prime examples of how the open court principle should be applied to a question of media access to court exhibits. Not only do these decisions correctly point out many of the errors commonly being made by judges across the country, but they also then proceed to reason through their decisions in a manner that is consistent with a broad interpretation of the open court principle and in line with the Supreme Court jurisprudence.

The trial decision in Hogg provides an excellent summary of what many of Canada's lower courts have been doing "wrong" with respect to the issue of media access to court exhibits. ${ }^{119}$ In Hogg, CTV applied for access to a videotaped statement of the accused made while in police custody and entered as an exhibit during a preliminary inquiry. The accused was charged with aggravated assault and pled guilty following the preliminary hearing. CTV intended to use the video in an episode of its W-FIVE program, which was to focus on conditional sentences (the accused was initially given a conditional sentence, which was later substituted with a sentence of incarceration). The Court of Queen's Bench cited the Dagenais/Mentuck test and ultimately denied CTV's application, finding that there was “a serious risk to the proper administration of justice.”120 The Queen’s Bench judge held that

$R v$ Canadian Broadcasting Corporation and Canwest Television (unreported, 2 May 2001, Man QB) at 3 , as cited in CTV, supra note 16 at para 8.

See e.g. Casement, supra note 41.

See Part II.A, above.

See Part II.B.1, above.

CTV Television Inc v R, 2005 MBQB 65, 191 Man R (2d) 292 [Hogg, QB].

Ibid at para 48. 
the requirement of open justice was met because the sentencing hearing and subsequent appeal were open to the public, there was no publication ban in any of the proceedings, and the written transcript of the proceeding was available to the media. ${ }^{121}$ The judge also held that CTV did not establish why it was important to have access to the video itself and therefore found that "one is left to assume that what it is seeking is a 'photo opportunity,"” which is not necessary to inform the public. ${ }^{122}$

In its appeal of the Queen's Bench decision, CTV argued that the "judge relied on unproven assumptions as to the effect that the release of the videotape would have" and essentially reversed the onus by requiring CTV to show that there would be no serious risk to the proper administration of justice. ${ }^{123}$ The Crown supported CTV in its appeal, arguing there was no compelling evidence for the judge to rely on in denying the application and that the reasoning used was "speculative, at best." ${ }^{124}$ The Court emphasized the importance of the open court principle by beginning its decision with the quote from Toronto Star cited at the beginning of this article: "In any constitutional climate, the administration of justice thrives on exposure to light - and withers under a cloud of secrecy." 125 The Court then correctly applied the Dagenais/Mentuck test by focusing on whether the release of the exhibit to the media would "unduly impair the proper administration of justice.”126 The Court agreed with the appellants' arguments, finding that the Queen's Bench judge had erred by basing "his conclusion on common sense and logic alone, without the benefit of real and substantial evidence."127 The Court held that this was not enough to rely on "when the effect of a decision is to limit a Charter right." 128 These criticisms of the Queen's Bench decision are demonstrative of the common mistakes being made by courts across the country in cases of this nature.

The British Columbia Court of Appeal's decision in Fry ${ }^{129}$ also discusses and rejects the faulty reasoning employed in many of the cases discussed earlier in this article. Fry was a case factually similar to both Casement and Black, as all three decisions considered media applications for access to exhibits related to undercover operations. In this case, Global BC and the CBC applied for permission to view and copy an undercover video recording and transcript. The media's application was made following the trial in which the accused was found guilty by jury of murder and attempted murder. The video itself depicted the accused describing and admitting his involvement in the fire and explosion which resulted in the deaths and injuries; it also contained footage of undercover officers and references to those officers and the surviving victim. The British Columbia Supreme Court cited the Dagenais/

$\begin{array}{ll}121 & \text { Ibid at para } 46 . \\ 122 & \text { Ibid at para } 47 .\end{array}$

123 Hogg, supra note 4 at paras 15-16.

Ibid at para 19.

Ibid at para 2, citing Toronto Star, supra note 2 at para 1.

Hogg, ibid at para 3. The issue of privacy, which would fall under the second step of the Dagenais/Mentuck test and which was argued at trial, was not before the Court of Appeal (ibid at para 14).

$127 \quad$ Ibid at para 33

128 Ibid at para 36. Prior to the release of the Court of Appeal's decision in Hogg, the validity of the Queen's Bench decision was questioned by a judge of the Quebec Superior Court in CTV Montreal c R, 2006 QCCS 7973, [2006] QJ no 24160 (QL). The Court there held that it is not "for the Court to prognosticate on the notion of sensationalism with regard to the use of exhibits or the manner in which they are used or diffused" (ibid at para 3). 
Mentuck test and denied the media's application, holding that the release of the exhibits would present a serious risk to the proper administration of justice and that editing either the video or the transcript to protect the identity of the officers and the victim was not a viable option. In regards to the video exhibit, the Court held that " $[\mathrm{t}] \mathrm{he}$ extensive editing and alteration of the exhibit that would be required to ensure anonymity would not result in the release of the exhibit, but rather in the preparation and release of a made-for-television version of evidence adduced at the trial, a use of evidence that is not conducive to the proper administration of justice." 130 The same concerns were given as justification for the Court's refusal to release the transcript: because portions of the transcript were missing due to inaudible sections of the recording, the Court held the transcript was also essentially edited and would not present a true picture of the evidence. Finally, the Court reasoned that denying access to the video exhibit was appropriate because the video contained a confession by the accused, but the accused's defence at trial was that the confession was false. The Court held that "[d]isclosure and broadcast of the video in any form would not permit the viewing public to assess the credibility of Fry's denial of the truth of the confession as a vast amount of other evidence in the trial affects that assessment."131

In a 2:1 decision, the British Columbia Court of Appeal reversed the lower Court's decision. The majority of the Court held that the trial judge erred in "considering whether a benefit or advantage to the administration of justice would be obtained by permitting publication (or in this case, providing copies to the media), rather than whether a serious danger would be avoided by declining to provide copies.”132 The Court also disagreed with the trial judge's finding that “'anything to be gained by release of the exhibit in a greatly modified form' was substantially outweighed by the need to protect the safety and privacy interests of the undercover officers and the other individual implicated." ${ }^{133}$ Instead, the majority of the Court held that editing the exhibits to protect the relevant identities "would achieve the objectives the trial judge sought to achieve by denying the release of the exhibits." 134 In the result, the Court of Appeal applied the Dagenais/Mentuck test and held that it was not necessary to deny access "in order to prevent any serious risk to the proper administration of justice" and that "the salutary effects of denying access ... do not outweigh the very strong presumption given by the Supreme Court of Canada in recent cases to the right of the public to have access to information of this kind."135

The majority decision in Fry strongly favours the broad interpretation of the open court principle argued for in this article, and engages in what has been argued is a proper interpretation of the Dagenais/Mentuck test. However, the dissent in this decision must also be noted as it conveys much of the same flawed reasoning exhibited by the cases discussed in Part III, above. The dissenting judge held that "the public's presumptive right to information has been met" through the playing of the exhibit in open court, which the media then had the opportunity to report on. ${ }^{136}$ The dissent also held that it was acceptable and appropriate for the trial judge to consider the additional factors that he did — such as the fact

\footnotetext{
$130 \quad$ Fry, SC, ibid at para 22.

Ibid at para 23.

Fry, supra note 5 at para 72.

Ibid at para 75 .

Ibid.

Ibid at para 78 .

Ibid at para 57.
} 
that extensive editing would result in a different product than what had been played in court. ${ }^{137}$ As a result, the dissenting judge would have denied the media's appeal, holding that the trial judge properly concluded that refusing the application "was necessary 'to prevent a serious risk to the proper administration of justice"” and "the salutary effect of denying [the application] outweigh[ed] the deleterious effect on the rights and interests of the applicants.” 138 Thus, despite these important judgments from the British Columbia and Manitoba Courts of Appeal, which could serve as a guide to the proper approach to issues of media access to court exhibits, the dissent in Fry demonstrates the continuation of conflicting views between various Canadian courts and judges as to what the open court principle entails and how the Dagenais/Mentuck test should be interpreted and applied.

\section{B. SuPREME CoURT OF CANADA GUIDANCE}

It should be said here that the purpose of this article is not to argue that media applications to exhibits should always be granted. In fact, many of the cases in which flawed reasoning was employed might still have come to the same end result had the proper approach been used, and many of the cases set out as good examples here resulted in only partial access to exhibits through the imposition of conditions to protect other interests. ${ }^{139}$ The point here is that, regardless of the result, proper and consistent reasoning, as seen in the appellate court decisions in Hogg and Fry, must be employed in all Canadian courtrooms in order to prevent the potential erosion of the open court principle. The reality is that although the decisions in Hogg and Fry got it "right," and a few additional cases from other jurisdictions have employed a similar analysis, the dissent in Fry and the other cases outlined above take a very different approach. Despite the holding in Toronto Star that the Dagenais/Mentuck test is applicable to all discretionary questions involving media access, this continuing divide in the case law demonstrates that stronger clarification is needed in this area of the law. In order to protect the open court principle, the Supreme Court of Canada should take its next opportunity to clarify the issue and put an end to the clear inconsistencies being played out in Canadian courtrooms. The Supreme Court should confirm the historical and continued importance of the open court principle, reiterate the Dagenais/Mentuck test, restate the appropriate onus, and explicitly state that the test applies to all discretionary orders regarding media access, including questions of access to exhibits. Until this happens there is a very real

Ibid at para 58.

Ibid [footnotes omitted].

A case not yet discussed that resulted in only partial access in response to a media request is $R v$ Hilderman, 2006 ABQB 107, 395 AR 218 [Hilderman]. In this case, the Court dealt with an application from a number of media outlets for the release of videotape evidence entered as an exhibit in a trial for aggravated assault. The request was made at the sentencing hearing of the accused, who had been found guilty of the crime depicted on the video. The Court applied the Dagenais/Mentuck test, confirming it as the test to be used for "[a]ll discretionary court orders which limit freedom of expression and freedom of the press in relation to legal proceeding[s]" (ibid at para 6). However, the Court only allowed the application in part, holding that the portion of the video depicting the actual assault could be released, but that the scene showing the accused urinating on the victim would be withheld. The Court reasoned that "it would be wrong to release an exhibit which may fairly be described as obscene or grossly indecent" (ibid at para 17). Broadcast of this material would offend public morals and the Court's complicity in that would impair the reputing of the administration of justice. In addition, at least one case was found in this research where a court correctly interpreted and applied the Dagenais/Mentuck test yet denied the media's application in its entirety because of a "real and substantial" risk of re-victimizing the deceased victim's family: $R v$ Dagenais, 2009 SKQB 104, 332 Sask R 244 at para 47. In this case, the CBC applied for the right to broadcast an audio recording containing the last words of an RCMP officer who was allegedly shot by the accused. The application was opposed on the basis that the broadcast of the exhibit would unduly harm the family of the officer. 
possibility that lower courts will continue to undermine the open court principle by applying improper tests and irrelevant considerations to questions involving media access to exhibits.

\section{CONCLUSION}

The open court principle, and the media's role in upholding it, is a central tenet of the Canadian justice system. Its recognition ensures that those accused of a crime receive a fair trial and that the public is able to see justice done. It is an invaluable component of our democratic society, yet it is currently being threatened by inconsistent decisions in Canada's lower courts. These courts have strayed from the historically accepted principle that courts are presumptively open and access should only be restricted in rare and specific circumstances. This has occurred despite the existence of the Dagenais/Mentuck test, which clearly sets out the steps to determine whether these specific circumstances exist, and despite the clear articulation that this is the test to be used in all discretionary decisions related to media access. There are decisions in this area which promote a narrow view of the open court principle, and future decisions of this kind must be avoided to preserve the integrity of the justice system. As such, the Supreme Court of Canada should take its next opportunity to reaffirm the importance of the open court principle, re-articulate the Dagenais/Mentuck test, and specifically state that the test applies to media applications for access to exhibits. A failure to act could jeopardize one of the most fundamental values in our justice system the open court principle. 